UDC 681.3.06, 004.89

\title{
A.Yu. PEREVARYUKHA* \\ DEVELOPMENT AND SCENARIO EXPERIMENTS WITH THE NEW MODEL OF RAPID BIORESOURCES CRISIS UNDER EXPERT CONTROL
}

\author{
${ }^{*}$ St. Petersburg Institute for Informatics and Automation of RAS, St. Petersburg, the Russian Federation
}

\begin{abstract}
Анотація. Ця стаття продовжує серію досліджень, присвячених аналізу нелінійної динаміки складних екологічних процесів за допомогою обчислювальних методів. У роботі розглядається побудова обчислювальної структури з використанням форм гібридного часу і логіки переочіненої поведінки рішень системи рівнянь для опису важливих нелінійних явищ при управлінні нестабільними біосистемами. Відмінність описаного підходу до побудови моделі полягає в тому, щзо обчислювальні експерименти на основі диференціальних рівнянь, сформованих згідно з правилами, імітують сиенарії в динамічі керованих біоресурсів різного типу. Форма часу дозволяє діяти з огляду на дискретну складову траєкторії з метою опису змін, помітних ззовні експертам, за даними статистики моніторингу або за звітами рибного промислу. Обчислювальна структура логічно відповідає життєвому ичиклу великих морських риб. Для регулювання змін у моделі жситтєвого ииклу використовуються безперервні характеристики. Нові моделі призначені описувати у сиенаріях складно з'ясовані явища стрімкої деградації цінних біоресурсів за незначних похибок у регулюванні норми вилучення з ресурсів. Розроблені моделі показали, що традиційні методи експертного управління біоресурсами мають суттєві недоліки і проблеми. Експерти завищують обсяги запасів риби для їх промислового вилучення з популящії. Регулювання вилову риб за допомогою встановлення спеціальних квот не запобігає руйнуванню промислу. Описаний підхід можна застосовувати для прогнозування стрімких фаз екологічних вторгнень у водні системи.
\end{abstract}

Ключові слова: гібридні системи, логічні моделі з керуванням, перевизначення рівнянь предикатами, коригування моделі розмноження і росту риб, сценарні обчислювальні експерименти, обтрунтування моделі, експертне управління, біфуркації в моделях екосистем.

\begin{abstract}
This paper continues a series of studies dedicated to the analysis of the nonlinear dynamics of complex environmental processes through the use of computational methods. The construction of a computational structure that uses the forms of the hybrid time and the logic of redefined behavior of solutions of the special system of equations to describe important nonlinear phenomena in the management of unstable biosystems is considered in the article. The difference between the described approaches to building a model is that computational experiments based on differential equations and redefined according to the rules simulate scenarios in the dynamics of controlled biological resources of different types. The form of time allows to operate on a discrete component of the trajectory to describe changes that are visible to experts from the monitoring statistics or from reports from the fishery. The computational structure logically corresponds to the life cycle of large marine fish. Continuous characteristics are used to manage changes in the life cycle model. The new models are intended to describe in scenarios the phenomena of rapid degradation of valuable biological resources with a very small error in the regulation of the rate of removal from the stock. These models have shown that the traditional methods of bioresources management by experts have fundamental shortcomings and problems. Experts overestimate the amount of stocks for commercial removal from the population. Regulation by setting quotas on fish catch does not prevent the fishery from collapsing. The approach is applicable for mathematical predicting of the rapidly inflowing phases of an ecological invasion in aquatic systems.

Keywords: hybrid systems, logical models with control, redefinition of equations by predicates, correction of the fish reproduction and growth model, scenario computational experiments, model justification, expert control, bifurcations in ecosystem models.
\end{abstract}




\section{Introduction}

In the series of previous works some original methods of mathematical formalization used for a complex of nonlinear factors necessary for the construction of computational models of ecosystem processes have been consistently developed. The phenomena of varying complexity and biological genesis have been analyzed as well. For the problem of a qualitative description of the situation, several models of natural processes built on the basis of functional iterations have been used, and for some purposes the calculations with continuous time have been constructed [1]. Using the idea of changing developmental stages, internal mechanisms for self-regulation of the reproduction efficiency of aquatic organisms populations have been modelled. Due to the use of some models aimed at decreasing the number of fish generations with a chaotic attractor, it was possible to describe mathematically some of the effects that were unexpected for the methods used for determining the fishing strategy and problems in the dynamics of commercial fish populations [2]. In the framework of three interdisciplinary projects, there has been carried out a simulation research of the influence of an external hydrological factor on the success of valuable fish species reproduction which was noted as a critical factor by many ecologists [3]. In a discrete model of logically connected blocks of equation units, using the calculation of trophodynamic changes in a reservoir, it became possible to verify a model for assessing the efficiency of valuable biological resources reproduction for a real reservoir - a large but shallow lake that was used by the Chinese industry. The new multicomponent model developed in [4] took into account the excessive development of primary producers of the lake (photosynthetic organisms) with the increasing eutrophication in the reservoir. The model has been verified on the Lake Chao in China. The monitoring of real data allowed to use a computational model to calculate a five-year prediction for the accumulation of nutrients at different levels of the food chain of the aquatic animal community.

In this article the construction of a model for the phenomenon of a threshold decrease in reproduction efficiency will be considered. Its effect will be reflected in the dangerous events of some fish populations collapse with a small increase in the permissible commercial mortality, as it has been observed for the halibut and the sturgeon fish of the Caspian Sea. This has influenced a rapid degradation of valuable populations many times. In another case, this effect can cause a rapid increase in the population size when species enter new conditions. Many processes in the dynamics of populations are now developing at high pace and with a rapid change of phases. In modern conditions, it's necessary to take into account activity of alien species-invaders in the form of outbreaks of reproduction in the models of populations, because the processes that take place during outbreaks can be replaced by a sharp degradation. Facilities for the counteraction of biosystems against the invaders can be switched on rapidly but with a certain delay.

\section{Actual mathematical properties of a new population model}

For a variety of situations of ecological confrontation between species that have reliably statistically determined threshold effects, an effective solution is to propose a general method for modifying the population model of the generation of successive generations. By the term «threshold effect» a sharp change in the efficiency of reproduction or a rapid increase in loss, which is disproportionate to the change in the total population size, is meant. A simple example can be given: if density of organisms in the experiment reaches is a critical one, then massive death will occur because of the lack of oxygen. Otherwise, insufficient numbers manifest themselves, as in social insects it leads to poor food availability and low survival of the offspring, in the Caspian sturgeon fish- to the loss of eggs at spawning grounds in the Volga River. The stellate sturgeon population practically died out and disappeared in the Caspian Sea before our eyes due to the failure of its artificial reproduction [5]. 
As a result of our improvement of methods, a theory of optimal bioresources management will be able to simulate a scenario capable of detailing the internal mechanics of feedback in transient environmental processes. For example, as a result of a slight excess of the level of impact, the scenario is rapid and unexpected for the biological degradation of previously numerous and valuable fish stocks. A classic example is the immediate collapse of the Canadian cod fishery in 1992-1993. The solution of such an important problem will be to show that various actual scenarios are common from the point of view of nonlinear dynamics and can be obtained through modifying systems of differential equations using the method of adding a trigger functional. The method is applicable to the analysis of situations in case of the bioresources collapse, rapid and unexpected degradation of fish stocks, which is not replaced by restoration contrary to forecasts and calculations provided by specialists.

For the problem of the description of situations, the computational scenarios with functional iterations $x_{n+1}=\varphi\left(x_{n}\right)+Q[n]$, where $Q[n]$ expresses a variable control function and $\varphi$ must have clear population properties, will be used. Five following mathematical properties of such iterative model for nonlinear effects are considered for a rigorous justification:

1. $\exists x_{0}<x_{1}, x^{*}>x_{1}: \lim _{n \rightarrow \infty} \varphi\left(x_{0}\right)=x^{*}$.

2. $\forall x_{0}>x_{1}: \lim _{n \rightarrow \infty} \varphi\left(x_{0}\right)=x^{*}$.

3. $\exists y_{0}<x_{1}: \lim _{n \rightarrow \infty} \varphi\left(y_{0}\right) \in \Lambda$,inf $\Lambda<x^{*}$.

4. $\forall x_{0}<x_{2}: \lim _{n \rightarrow \infty} \varphi\left(x_{0}\right)=0$.

5. $\varphi\left(x_{\max }\right)>x_{1}, \varphi\left(x_{\min }\right)>x_{2}, x_{\max }<x_{\min }$,

where $\Lambda$ is a local attractor, $x^{*}$ is a fixed point of an iteration $\varphi$ with $x_{0}$ as a start point. These five properties mean that the function $\varphi$ must have at least two extremum points. Set $\Lambda$ often arise as a disconnected set of intervals. This property of local disconnectedness of the attractor $\Lambda$ will be considered in details later. Near each point of this attractor there are points from the boundary $\partial \Lambda$ of its area of attraction. It is important that the function $\varphi(x)$ will have multistability as an ability to attract a trajectory of the initial point $x_{0}$ to different attraction sets. An important change in the scenarios will be the value that the function takes at the points of its extremes. The equilibrium states in the iteration model can appear and disappear. The number of the equilibrium positions cannot be fixed, its value ranges from 2 to 4 points. The characteristics of the models, which follow from the properties of functional iterations, often cannot be predicted at the stage of a model construction.

These properties allow to implement the necessary and justified non-linear effects and correct bifurcations in the model, while in this way incorrect modes, unnecessary bifurcations and chaotic motion can be avoided. A modernized idea of the existence of a mathematical relationship in the efficiency of fish reproduction as the theory of nonlinear threshold realization of the reproductive potential of populations is defined. Some of the reasons for the modifications relate to the mathematical properties of function iterations, not to the essential biological interpretation.

\section{Mathematical improvement of a biological theory of the replenishment of stocks for- mation}

Ecodynamic models must assess variability for the development of a situation in a changing environment. Biological justification for the application of the numerical solution of a continuous model within a time interval in a form of an evolution operator in discrete iterations is based on the Ricker theory of the replenishment of fish stocks formation. The theory was developed to analyze the management of the pink salmon fishery in British Columbia in [6]. It has several modern variants and modifications [7] with different functions [8]. Their difference is in the occurrence of nonlinear effects in the dynamics of iterations. These bifurcations are obtained for different 
models of the opposite interpretation. The parameters in the ecodynamics models are interpreted in completely different ways, but their increase causes the same rearrangements of the phase portrait and bifurcations of attractors. The «Feigenbaum cascade» is an example of behavioral versatility - the phenomenon that many authors, against their will, observe when calculating models of the dynamics of bioresources. In [9] A.V. Nikitina purposefully and competently avoids chaotic effects during mathematical modeling of eutrophication processes in the Sea of Azov. The models, developed by A.V. Nikitina for hydrobiological processes, require computations on supercomputers [10]. V.V. Mikhaylov used models based on algorithmic networks with thousands of nodes [11]. Our models can be calculated by using simple free program tools such as a laptop and a computational workbench tool Rand Model Designer [12].

The computational structure of replenishment models was previously successfully applied only to stocks which are in a stable state, not under extreme conditions. To simulate a situation influenced by drastic changes, the model should be expanded, and the examples of contradictions for two functions are to be considered. For the famous Ricker function $\psi(x)=a x e^{-b x}$ developed in [6], there are the following strict properties of older derivatives of $\psi(x)$ :

$$
\begin{aligned}
& \psi^{\prime}(x)=a \mathbf{e}^{-b x}(1-b x), \\
& \psi^{\prime \prime}(x)=a b \mathbf{e}^{-b x}(b x-2), \\
& \psi^{\prime \prime \prime}(x)=a b^{2} \mathbf{e}^{-b x}(3-b x), \\
& \psi^{(n)}(x)=(-1)^{n} a b^{n-1} \mathbf{e}^{-b x}(b x-n), \\
& S_{\psi=b^{2}} \frac{-b^{2} x^{2}+4 b x-6}{2(1-b x)^{2}}, \text { thus } S_{\psi<0} \forall x \in \Re .
\end{aligned}
$$

If the Schwarzian derivative $S_{\Psi}$ is always less than zero, then the chaotization in this model will certainly be at a low value of the reproductive parameter $a$.

For the alternative Shepherd function $f(x)=a x / 1+(x / K)^{b}$ from [13], the following relations of the bifurcation parameters of the derivative are obtained through the analogous procedures at the stationary points of all iterations $\forall n: f\left(x^{*}\right)=f^{n}\left(x^{*}\right)$ :

$$
\begin{aligned}
& f\left(x^{*}\right)=x^{*}=K \sqrt[b]{a-1} \\
& \frac{d f(x)}{d x}=\frac{\left(K^{b}+x^{b}\right) a K^{b}-a b(K x)^{b}}{\left(K^{b}+x^{b}\right)^{2}}, \frac{d f\left(x^{*}\right)}{d x}=\frac{a-b a+b}{a} .
\end{aligned}
$$

For $b<1$ there are no critical points, for $b=2$ the reproductive function of the stock and recruitment has a critical point $x=K$, but $K$ is a carrying capacity of an ecological area. Thus, parameters $a$ and $b$ have the opposite interpretation, and the behavior of the models cannot be reconciled. Therefore, a fluctuation model for fish stocks without a cycle period-doubling cascade should be developed. Compared to previously known models, our new development will be able to generate brief chaos modes. Such regimes of chaos are very limited in time and can be detected on the basis of observational data on the state of the population. Some modern researchers, when constructing the models of aquatic biosystems, deliberately construct discrete equations without the possibility of any chaotic regime. The appearance of the chaos regime is unpredictable, it reduces the possibilities for interpreting the simulation results.

\section{The ideas of the method for the construction of a hybrid model structure}

The main problem of modeling processes with different scales of flow rate is to synchronize time in calculations. The lifetime scale does not match with the intervals of the statistical data [14]. 
New equations with continuous time will be elaborated, and isolated events at this time will be included. To build a computational model of populations with clearly defined stages in the development of individuals, a structure of time with a discrete and continuous time component is used. It was decided to create a method for analyzing nonlinear processes on the basis of a mathematical description of the survival of generations of populations in early ontogenesis. The approach can be improved in several ways. To the changing conditions and factors in ecological and physiological development of species, our computational models are logical to form in an algorithmic way as logical-event structures and to consider them as scenarios. The first idea of our method is that the new model of a population process is formed on the basis of a dynamically redefined system. Talking about fish- and insects-related environmental problems, the key biological aspect allows us to consider the consequences of changes in their life cycle as a factor of nonlinear dynamics. The given time introduces an event component to the management of the change in a continuous process as a composition of sets. A hybrid time have been formalized as the following multiset of disjoint intervals:

$$
\bigcup_{n}\left\{R_{-} \tau_{n},\left[t_{n-1}, t_{n}\right], L_{-} \tau_{n}\right\}
$$

Where $R_{-} \tau, L_{-} \tau$ are time gaps of the hybrid model time set of continuous intervals, $t_{m}$ is an intra-frame time threshold. This time (1) with right and left time gaps form with a continuous and discrete component is constructed from a set of ordered frames of non-fixed length. The second idea of the method is to establish events with a set of predicates of the first order, with which the changes in the system or control action are associated.

The method of organizing continuous-event computing structures was originally proposed to explain the problem of low efficiency of sturgeon artificial reproduction in the Caspian Sea. Such a low effect of the release of fry to the Caspian Sea could not be explained by ichthyologists [15]. To build a model of phased ontogenesis, a predicatively redefinable computational structure with three successive modes of change in the generation state is proposed. There is always a delay in natural processes, but its inclusion $N(t-\eta)$ in continuous equations greatly changes the behavior of their solutions. Below is presented a new formula of a general model with generalized three stages of the ontogenetic development in the interval but with the inclusion of time delay $\eta$ :

$$
\frac{d N}{d t}=\left\{\begin{array}{l}
-\left(\alpha_{1} w(t) N(t)+\beta\right) N(t), t<\tau, \\
-\alpha_{2} N(t) / w(\tau)-\beta N(t), t>\tau, w(t)<\bar{w}, \\
-\alpha_{3} w(t) N(t) N(t-\eta), t_{w}<t<T,
\end{array}\right.
$$

where $w(t)$ is an indicator for size development of individuals, $\alpha$ and $\beta$ are juvenile mortality rates, $\lambda$ is an average fertility of individuals in the population, $S$ is the amount of parent fish stock and $N(0)=\lambda S$. The system (2) is written through a differential equation with a set of possible forms for the right part and additionally with a set of predicates for changing the mode of calculations. In the hybrid model time (1) juvenile mortality rates of fish or insects are interpreted differently. The parameter value $\bar{w}$ is necessary as a threshold level of average dimensional development for a generation. The form for the implementation of the models (1) and (2) in the computing environment is a hybrid automaton. Such an automaton is constructed with some transitions on the basis of a graph with oriented arcs - the ways of transforming the right-hand side. Three rebuildings of the right-hand side of (2) occur either by timing the time (such transitions will be called «timed arcs») or predicative transitions (by calculating internal model variables) that will be associated with the conditions of other equations in the system. In our method, the changes will be between the state change modes. It differs from the transitions between the states themselves, as it was typical for discrete-event models. A basic hybrid structure is solved numerically 
in a conjunction with an auxiliary indicator of the dimensional development of a generation. The second equation for an example of the simulation of young sturgeon artificial cultivation is written as follows (3) with the correction indicator $\delta$ under the square root:

$$
\frac{d w}{d t}=\frac{\mu}{\sqrt[3]{(N(t) N(\tau)+\delta)^{2}}},
$$

where $\mu$ is a food supply parameter for the generation. The model (3) fixedly reflects the availability of food supply, otherwise, if there is a need for such a complication for a given ecology task, the indicator $\mu$ can be described dynamically with the help of the third equation.

The method, which allows us to expand the base model, made the idea meaningful for the extreme dynamics of many invasive species with high fecundity of females, for example, for sudden outbreaks of such insects as aphids and psyllids which have an incomplete cycle of transformations. These insects have no natural defense against enemies. The state and activity of many harmful insects of phytophages are regulated by their enemies - parasites. Parasitic wasps usually attack pests at one of the stages of their development (most often they attack eggs). The reaction of parasites is stipulated by the presence of clusters of available victims - the value $N(0)$. The reaction to the initial number of insect eggs will cause this modification for the specific survival of insects in $t<\tau$ time:

$$
\frac{d N}{d t}=-\left(\alpha_{1} w(t) N(0)+\beta\right) N(t)
$$

It is important to calculate numerically the fluctuations of juvenile survival of insect species $N(0) \rightarrow N(T) \equiv \varphi(N(0))$. A functional dependence on the initial (eggs, spawn fish caviar) group of individuals $N(0)=\lambda S$ in the model variation (4) will be obtained. The reaction of their enemies is stipulated by the crowding of the victims most accessible to attack. Then some examples of the modification of the model of equations (2) and the new equation (4) formed by using our method of trigger functionals for the cases of special situations in the dynamics of fish and insects will be considered. After that a series of computer experiments for hybrid models with trigger effects will be reviewed and shown.

\section{Main results of computational experiments}

Computational experiments have been carried out to compare different scenarios of population response in expert management of the commercial exploitation of fish resources and to predict recovery of fish stocks. Knowing a rate of fish stocks recovery has a large economic impact [16].

The method has been successfully applied to calculate the reproduction of sturgeon in the Caspian Sea, but for other fish populations it turned out to be even more relevant. The role of unfavorable environmental conditions in the reproduction of populations increases considerably. According to the obtained data, the spawning efficiency of the starry sturgeon (Acipenser stellatus) and the complete destruction of a small population of the Persian sturgeon (Acipenser persicus) [17], in terms of the number of juveniles that move from the river Volga to the Caspian Sea, decreases sharply if the number of spawning fish stocks (due to systematic overfishing) becomes less than at the threshold. The Allee effect is a known reason of this threshold [18].

A disproportionate reduction in reserves replenishment cannot be foreseen by correlation methods. The novelty of this approach is that it provides an introduction into the hybrid, as well as a predicatively redefinable dynamic system of trigger functionals with a limited area of impact taken from the conditions of the ecological problem that is being solved by the proposed new models.

In the equation of decay (1) for the number of generations, there are two death rates which are directly dependent on the population density $\alpha$ and the independent rate $\beta$. The value $\alpha$ takes 
into account the quickest exhaustion of resources, necessary for the development, as a number of larvae increases. It turned out to be important for assessing the stocks of migratory fish, and, taking into account a low density of fish producers entering the river, it makes sense to consider the loss of their reproduction at the stage $t=0$. The effect of the loss of reproductive activity of fish is implemented into the model with a trigger functional $\Psi[S]$, and with a limited range of values it looks as follows:

$$
\begin{aligned}
& \Psi(S)=1+\exp \left(-\sigma S^{2}\right), \\
& \lim _{S \rightarrow \infty} \Psi(S)=1, \Psi(0)=2, \\
& \frac{d N}{d t}=-\alpha w(t) N^{2}(t)-\Psi[S] \beta N(t) .
\end{aligned}
$$

In this additional function a new parameter reflects the severity of the threshold effect which acts because of the reduced probability of spawning fish pairs in the river. The numerical solution of the system supplemented by the functional in (5), an operator of the evolution of functional iterations is used. The phase porters for iterations $R_{n+1}=\varphi\left(R_{n}\right)-q R_{n}$, where $q \in[0,1)$ is a proportion of the harvest taken from the fish stock, are investigated. Now the value $\mathrm{R}$ reflects the population size.

Despite the fact that the regions of attraction of these alternative stable states were separated by a fractal set of boundary points, a trajectory with two possible asymptotic states has been obtained. The formation of a chaotic repeller with a change in the position of the extremes of dependence $\varphi(\lambda S)$, generates a type of a transitional chaotic motion different from the one used in the well-known Feigenbaum attractor [19].

Let assume that the simulated population has an extremely high reproductive potential, but the exploitation of the stocks slightly exceeds the possibilities for the restoration of biological resources. The Caspian sturgeon and the Atlantic cod were distinguished by the high rate of their fertility. In our computational experiment scenario of the commercial stocks collapse develops

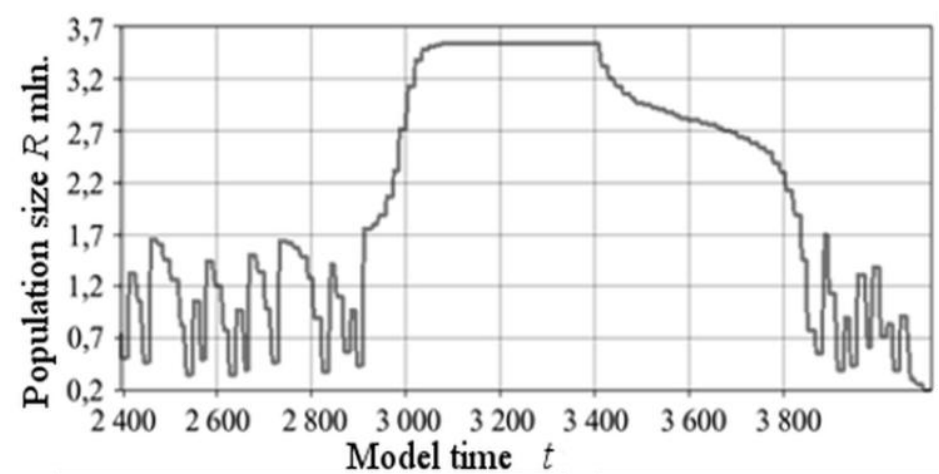

Figure 1 - The scenario model of the collapse of the population that has a high reproductive potential from two following phases: 1) a population can become stable only after an increase in the commercial withdrawal in the aperiodic mode of fluctuations with a smaller number, but with the illusion of recovery; 2) for the situation when a moratorium was not introduced in a timely manner, in a 12 seasons model the second phase of degradation, named «collapse», will occur as in the model presented in Fig. 1.

In the conducted simulation experiment the collapse of the population that has a high fertility rate $\lambda>3 \times 10^{6}$ looks like a natural outcome. For the experts in fishery management this scenario became a sudden disaster.

The developed model allows us to consider several variants of the process which ends in collapse. In fact, collapse is a final and terminal phase of the long-term population regime in fishery management. This fishing regime is established by experts who want to optimize economic profit. A collapse can also occur for the population in which regular oscillations are observed. However, from a mathematical point of view, the oscillatory scenario requires different bifurcations. A period-doubling bifurcation is not identical to the Hopf bifurcation, since in discrete iterations there obtained cycles with symmetric points and only an even value of the period. It is dif- 
ficult to obtain a cycle with a peak at the end of the period in a discrete model. In the theorem presented by A.N. Sharkovsky there is nothing said about narrow parametric ranges for the cycles with an odd period.

The methods for assessing the stocks of sturgeon and cod significantly overestimated their actual number of fish. The official catch of cod stopped too late. For the Caspian Sea sturgeons the phase of pseudo-stabilization of the stock has been stretched for 15 years, from 1977 to 1992 , but the phase of a sharp fall in the catch is similar to the collapse of cod in Canada. In Fig. 2 a real example of the difference between the scenario of the gradual depletion of cod stocks and the collapse scenario that occurred off the coast of Canada [20]. There were two crises with a sharp decline in catches.

In history there were many examples of aggressive fishing without a scientific regulation. The fall in stocks and the collapse of short-cycle fish also proceeds in two stages in a similar way [21]. A real dynamics of the catch of anchovy fish off the coast of Peru, which collapsed in 1982, have been analyzed. The phases before the collapse are similar to the previously mentioned examples. At the same time there is an obvious difference - anchovy recovery is more efficient than Canada's cod multi-age stock. Population outbreaks are typical for small, numerous and rapidly maturing fish species. The cod matures for a long time, the sturgeon - for a very long time. To recover from small groups they need to go into short-cycle forms. The cod near the costs of Canada has not recovered in a quarter of a century since 1992. The collapse of the Atlantic cod is the largest in terms of economy, but not the most difficult version for such a promising environmental phenomena.

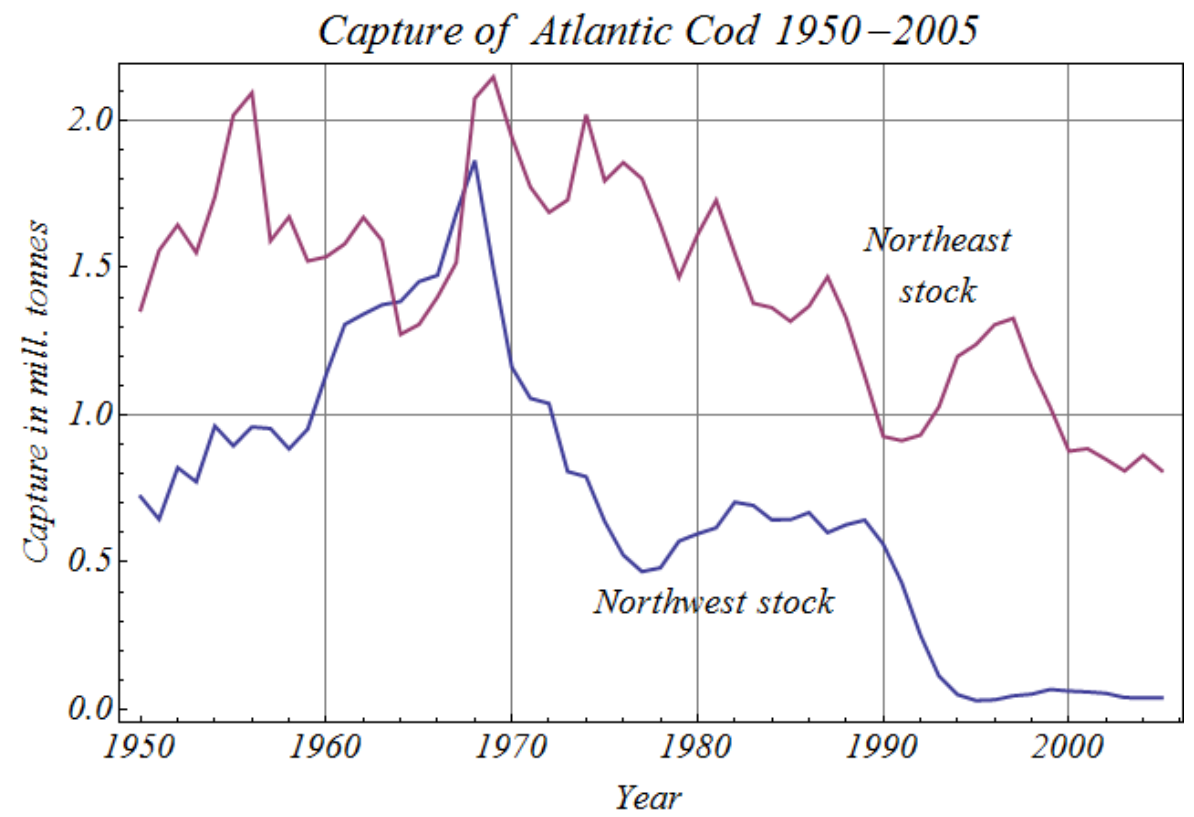

Figure 2 - Comparison of the dynamics of two commercial cod populations in the collapse scenarios

\section{Conclusions}

According to the presented model, the collapse scenario is a natural development of a situation under expert control. Experts assess the prospects of bioresources in this mode of population changes absolutely incorrectly. The process of degradation consists of two or three phases. The number of phases before the collapse depends on the average fecundity of the species. Fertility is a more important factor than the length of the life cycle in the ontogeny of the given biological species [22]. Stock collapse develops rapidly and it cannot be stopped. However, there have been shown two phenomena that can be treated as signs and harbingers of the future collapse. Fishing moratoriums for one season should be introduced at the first clear signs of stock reduction. The regulation through the use of a constant quota does not help to prevent the risks of the collapse, 
and a variable quota likewise does not guarantee optimal control. Only a limit on fuel for vessels ships can prevent rapid overfishing of biological resources. The sturgeon fish of the Caspian Sea can no longer be saved, but the Atlantic cod will restore its abundance near the Canadian cost. In further researches various data on collapse situations of bioresources such as anchovy, stellate sturgeon, cod, crab and the Black Sea salmon (Salmo labrax) will be analyzed. The goal for these future surveys is to find common dynamic characteristics of such events and build a continuous model of the food chain. The population always falls into an unstable regime of fluctuations in abundance after large catches [23]. Some populations, like anchovies in Peru, can quickly rebuild stocks after the collapse and decades of degradation.

\section{Acknowledgment}

The research has been carried out in the framework of the project based on the state assignment SPIIRAS N 0073-2019-0003, and financially supported by the Russian Foundation for Basic Research, projects N 19-37-90120, N 18-01-00626 and N 20-07-00839.

\section{REFERENCES}

1. Борисова Т.Ю., Переварюха А.Ю., Трофимова И.В. Проблемные аспекты моделирования популяционных процессов и критерии их согласования. Математичні машини і системи. 2017. № 1. C. $71-81$.

2. Переварюха А.Ю. Качественно различные динамические режимы в новых моделях биологических процессов. Математичні машини і системи. 2013. № 2. С. 118-129.

3. Гутенева Г.И. Влияние волжского стока на естественное воспроизводство осетровых рыб. Рыбное хозяйство. 2015. № 3. С. 103-105.

4. Яцишин А.В., Переварюха А.Ю., Михайлов В.В. Разработка, верификация и сценарные эксперименты в агрегированной модели трофодинамики крупного водоема. Математичні машини $i \mathrm{cu-}$ стеми. 2019. № 2. С. 90-100.

5. Veshchev P.V., Guteneva G.I. Efficiency of natural reproduction of sturgeons in the Lower Volga under current conditions. Russian Journal of Ecology. 2012. Vol. 43, N 2. P. 142-147.

6. Ricker W. Stock and recruitment. J. Fisheries research board of Canada. 1954. N 11. P. 559-623.

7. Bobyrev A.E., Burmensky V.A., Kriksunov E.A., Medvinsky A.B. Long-period endogenous oscillations in fish population size: mathematical modeling. Biophysics. 2013. Vol. 58, N 2. P. 245-257.

8. Kriksunov E.A. Resource availability and its role in development of invasion processes. Biology Bulletin Reviews. 2011. Vol. 1, N 1. P. 57-65.

9. Nikitina A.V., Semenyakina A.A. Mathematical modeling of eutrophication processes in Azov sea on supercomputers. Computational Mathematics and Information Technologies. 2017. Vol. 1, N 1. P. 82101.

10. Никитина А.В., Семенов И.С. Моделирование процессов эвтрофикации мелководного водоема. Известия ЮФУ. Технические науки. 2013. № 4. С. 37-44.

11. Mikhailov V.V., Yu.S. Reshetnikov Model of fish population dynamics with calculation of individual growth rate and hydrological situation scenarios. Информационно-управляющие системы. 2018. № 4 . C. 31-38.

12. Perevaryukha A.Y. Phenomenological computational model for the development of a population outbreak of insects with its bifurcational completion. Mathematical Models and Computer Simulations. 2018. T. 10, N 4. C. $501-511$.

13. Shepherd G.A. versatile new stock recruitment relationship for fisheries and the construction of sustainable yield curves. J. Cons. Int. Explor. Mer. 1982. Vol. 40, N 1. P. 67-75.

14. Ricker W.E. Two mechanisms that make it impossible to maintain peak period yields from stocks of Pacific salmon and other fishes. J. of the Fisheries Research Board of Canada. 1973. Vol. 30. P. 1275 1286.

15. Dubrovskaya V.A., Trofimova I.V. Model of dynamics of structured sub-populations of sturgeon fish in the Caspian Sea takes into account deviations in the rate of development of immature fish. Journal of the Belarusian State University. Biology. 2017. N 3. P. 76-86. 
16. Переварюха А.Ю. Моделирование эффекта волнообразной кривой воспроизводства популяций рыб. Экологические системы и приборы. 2008. № 8. С. 41-44.

17. Гутенева Г.И. Эффективность естественного размножения и биологическая характеристика производителей персидского осетра Acipenser persicus Borodin в условиях зарегулированного стока Волги. Вестник Астраханского государственного технического университета. 2015. № 4. С. 1520.

18. Розенберг Г.С. Уорд Клайд Олли и принцип агрегации особей. Самарская Лука: проблемы региональной и глобальной экологии. 2020. Т. 29, № 3. С. 77-88.

19. Feigenbaum M. J. The transition to aperiodic behavior in turbulent system. Communications in Mathematical Physics. 1980. Vol. 77, N 1. P. 65-86.

20. Rose G.A. Does redistribution or local growth underpin rebuilding of Canada's Northern cod? Canadian Journal of Fisheries and Aquatic Sciences. 2018. Vol. 75. P. 825-835.

21. Barrett R. Population dynamics of the Peruvian anchovy. Mathematical Modelling. 1985. Vol. 6, Iss. 6. P. 525-548.

22. Соловьева Т.Н. Модель сценария деградации каспийской севрюги с осциллирующей составляющей популяционной динамики. Информаџионно-управляющие системы. 2017. № 6 (91). С. 58-65. 23. Бобырев А.Е., Бурменский В.А., Криксунов Е.А., Медвинский А.Б., Мельник М.М., Нуриева Н.И., Русаков А.В. Анализ колебаний численности популяций промысловых рыб ПсковскоЧудского озера. Биофизика. 2012. Т. 57, № 1. С. 140-145.

Стаття надійшла до редакиії 26.01.2021 